\title{
Hypertensive-Nimodipine Therapy for Middle Cerebral Artery Vasospasm after Resection of Glioblastoma Multiforme: A Case Report and Literature Review
}

\author{
Peter Yat Ming Woo, Ka Wing Michael See, Jason Kwan Ho Chow, Yung Chan, \\ Hoi Tung Wong, Kwong Yau Chan \\ Department of Neurosurgery, Kwong Wah Hospital, Hong Kong, China \\ Email: peterymwoo@gmail.com
}

Received 26 April 2015; accepted 23 June 2015; published 26 June 2015

Copyright (C) 2015 by authors and Scientific Research Publishing Inc.

This work is licensed under the Creative Commons Attribution International License (CC BY).

http://creativecommons.org/licenses/by/4.0/

\section{(c) (i) Open Access}

\begin{abstract}
Delayed cerebral ischemia (DCI) due to post-brain tumor resection vasospasm is an often unrecognized yet debilitating complication. We present a patient with DCI after the resection of glioblastoma multiforme (GBM). To our knowledge, this is the first report on DCI after GBM resection. A 52-year-old female patient with headache for one month underwent subtotal resection of a left temporal GBM encasing the proximal middle cerebral artery (MCA). She was well during the immediate postoperative period but developed right upper limb dense monoparesis on postoperative day four with computed tomographic angiography confirming left MCA vasospasm. Symptoms were significantly alleviated with weeklong hypertensive therapy and nimodipine administration; however they recurred soon after cessation of treatment. A high index of clinical suspicion is needed for the diagnosis of post-tumor resection DCI. Any new postoperative neurological deficit that cannot be explained by hemorrhage, seizures or infection should be expeditiously investigated by angiography or transcranial Doppler sonography. Prompt initiation of hypertensive and nimodipine therapy can possibly reverse neurological deficit. Treatment should be guided by Doppler, angiographic or perfusion imaging studies and not by clinical improvement alone.
\end{abstract}

\section{Keywords}

Cerebral Vasospasm, Delayed Cerebral Ischemia, Glioblastoma Multiforme, Hypertensive Therapy, Nimodipine 


\section{Introduction}

Vasospasm associated delayed cerebral ischemia (DCI) after brain tumor resection is a rare complication. While DCI is well documented in aneurysmal subarachnoid hemorrhage (SAH), occurring in 30\% of patients, fewer than 50 cases have been reported following brain tumor resection [1] [2]. Resulting morbidity can be severe since the complication is often left unrecognized before timely treatment is initiated. It can be particularly distressful for patients, who often are preoperatively neurologically intact, and the neurosurgeon, responsible for an otherwise uneventful elective procedure [1]. Hemiparesis is the commonest manifesation and the time interval from tumor resection to symptom onset is comparable to aneurysmal SAH, peaking at seven days, although the complication can occur 30 days after the operation [1]. The pathogenesis of DCI in this setting is not clearly understood. Proposed causative factors include blood spillage in the subarachnoid space, operative manipulation of vessels and the release of vasoactive substances from the tumor [1] [4]. There is no widely accepted management strategy for post-tumor resection DCI and more than 70\% of patients have either severe disability or death despite medical treatment, compared to $19 \%$ - 46\% of SAH patients [1] [3]. We present a patient where neurological deficit due to DCI was partially reversed with hypertensive therapy and nimodipine administration, but recurred soon after discontinuation.

\section{Case Report}

A 52-year-old right-handed female with good past health had a headache of increasing severity for one month. The patient was fully conscious with right homonymous superior quadrantanopia. There was no other neurological deficit. Magnetic resonance imaging (MRI) revealed a left temporal intra-axial heterogeneously contrastenhancing tumor with midline shift (Figures 1(a)-(b)). MR angiography showed that the tumor encased the middle cerebral artery (MCA) displacing it antero-superiorly (Figure 1(c)).

Craniotomy for subtotal excision of the tumor was performed with neuronavigation and intraoperative ultrasound assistance to localize the MCA. Subpial tumor resection was performed conducted using a cavitron ultrasonic aspirator. The proximal trunk and the bifurcating branches of the M1 segment were encountered and preserved using this technique. Microdissection was used to protect the lateral lenticulostriate arterial perforators that were traversing the lesion. No further dissection was performed when confronted with highly adherent tumor tissue (Figures 2(a)-(b)). The histological diagnosis was glioblastoma multiforme (GBM) demonstrating methylguanine methyltransferase promoter region (MGMT) methylation and wild-type isocitrate dehydrogenase-1 (IDH-1).

During the early postoperative period the patient was well with no discernible additional neurological deficit. On postoperative day four she experienced right upper limb dense monoparesis of Medical Research Council grade 2/5 and aphasia. The patient was afebrile and cerebrospinal fluid analysis did not indicate infection. Computed tomography (CT) revealed new hypodensities at the left frontal and insula cortex compatible with cerebral ischemia (Figures 3(a)-(b)). CT angiography depicted narrowing of the proximal left M1 segment of the
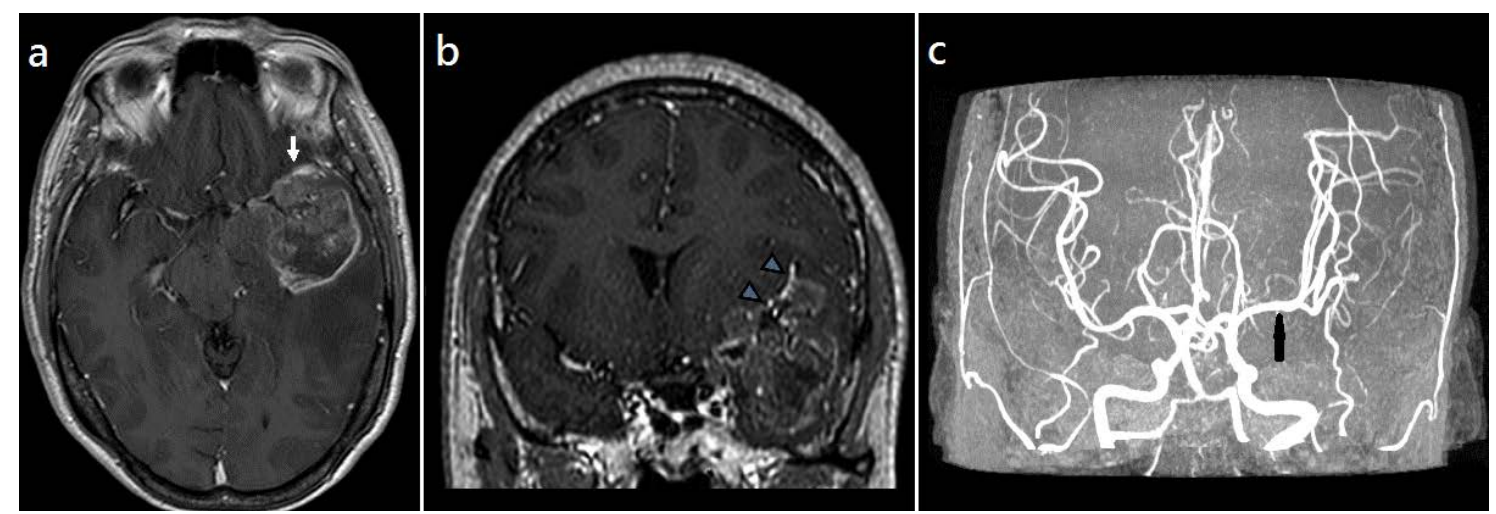

Figure 1. (a) Preoperative axial MRI showing a $3.7 \times 4.2 \times 4.5 \mathrm{~cm}$ left temporal intra-axial tumor with heterogeneous enhancement. Note the anterior displacement of the MCA (arrow); (b) Coronal MRI shows similar findings (grey arrowheads); (c) MR angiography before the operation showed superior displacement of a normal caliber MCA (black arrow). 

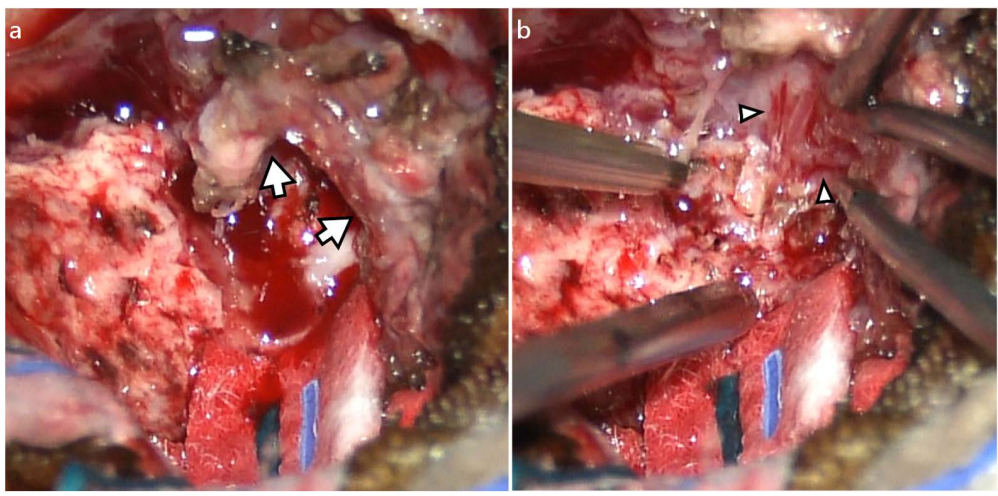

Figure 2. (a) The M1 segment of the MCA was completely dissected away from the encasing tumor (white arrows); (b) MCA branches and its perforators traversing the lesion were encountered and preserved (white arrowheads).

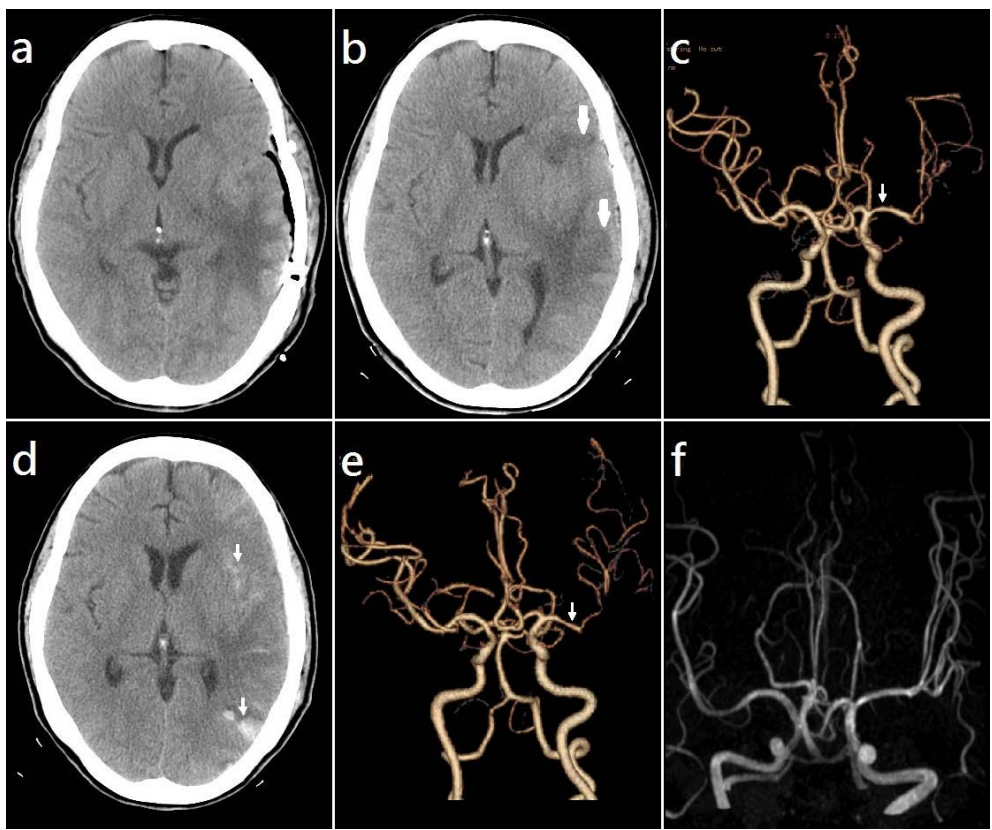

Figure 3. (a) CT on postoperative day 1; (b) CT on postoperative day 4 showing hypodensities over the left frontal and insular cortex (arrows); (c) CT angiography on day 4 demonstrating vasospasm (arrow) of the M1 segment of left MCA (arrow); (d) CT scan after cessation of hypertensive-nimodipine therapy showing luxury perfusion (arrows); (e) CT angiography demonstrating persistent MCA vasospasm (arrow) after hypertensive-nimodipine therapy; (f) 6-month MR angiography showing reconstitution of the left MCA.

MCA that was compatible with vasospasm (Figure 3(c)). Transcranial Doppler sonography (TCD) could not be performed due to a suboptimal bone window.

In view of DCI systemic nimodipine (60 mg orally every four hours) was started. In addition induced hypertension was administered by intravenous noradrenaline and dopamine to achieve a mean arterial pressure of greater than $110 \mathrm{mmHg}$ and systolic blood pressure greater than $160 \mathrm{mmHg}$ i.e. $20 \%$ above baseline. The patient responded to treatment over the course of five days with improved limb power to grade 4/5 and partial speech recovery to short sentences. After cessation of the weeklong therapy the patient developed a second episode of dense hemiparesis and aphasia. A CT scan revealed evidence of luxury perfusion that was managed expectantly (Figure 3(d)). A repeat CT angiogram showed persistent MCA vasospasm with progressive involvement of the temporal branch of the M2 segment (Figure 3(e)). This time the patient failed to improve after reintroduction of 
hypertensive therapy and intensive rehabilitation. Upon discharge the patient's functional performance was a modified Rankin scale score of four and a Barthel Index of 62. In view of her severe disability the patient received palliative adjuvant radiotherapy without chemotherapy. A six-month follow-up MRA showed reconstitution of left MCA patency and reemergence of its temporal M2 segment branch (Figure 3(f)).

\section{Discussion}

Delayed cerebral ischemia as a consequence of arterial vasospasm is a rare but debilitating complication after tumor resection. A large clinical series of 470 patients with skull base tumors observed an incidence of $1.9 \%$ and current understanding is mainly limited to sporadic case reports [4]. The results of this complication are severe with almost half of patients experiencing permanent major neurological deficit [1]. When a malignancy with a poor long-term prognosis such as GBM is concerned, postoperative quality of life and functional performance are vital in determining the aim of adjuvant oncological therapy. In our case this unexpected complication led to the administration of palliative radiotherapy despite a favorable chemotherapy predictive biomarker profile. The commonest pathologies associated with vasospasm are pituitary adenomas and meningiomas [1]. For unknown reasons, DCI occurring after malignant brain tumor resection is rare with only four previously confirmed cases, involving medulloblastoma, esthesioneuroblastoma, primitive neuroectodermal tumor and metastatic adenocarcinoma [23] [26] [30] [32]. Despite GBM being the commonest primary malignant brain tumor in adults, to our knowledge this is the first report of postoperative vasospasm in the literature [5].

Risk factors predictive of post-tumor resection vasospasm can be broadly classified into patient, tumor and surgical factors. It is believed that the single most influential patient factor is age. A recent review of the literature observed that most patients with vasospasm were young with a mean age of 41 years (1 to 69) and is comparable to SAH patients where the mean age is 48 years [6]. This predilection for vasospasm occurring in younger patients may be related to increased vasoconstrictive reactivity in response to mechanical arterial stretching or subarachnoid blood metabolite irritation [6]-[8].

Several contributive tumor factors have been identified and lesion location is crucial. Most tumors were observed to be in the sellar, parasellar and middle cranial fosse regions in close proximity to the Circle of Willis [1] [9]. Similarly tumor arterial encasement and narrowing are also considered significant risk factors [1]. Increased tumor vascularity with subsequent blood spillage into the cisternal space has been a recognized tumor feature in over $40 \%$ of cases [1]. However, in our patient postoperative hemorrhage was minimal. It is also relevant to discuss the role of metabolic changes within the peritumoral microenvironment in relation to malignant gliomas. Potent vasoactive cytokine levels of endothelin-1, platelet-derived growth factor (PDGF) and interleukin-6 are known to be elevated [10]-[12]. These cytokines have been demonstrated to induce vasospasm in animal models and up-regulated PDGF receptors in the endothelium of tumor arterial feeders could predispose parent arterial vasoconstriction [13] [14]. Microdialysis studies during biopsy procedures on malignant glioma patients have also detected increased levels of glutamate in necrotic areas that can theoretically be released during resection [15]. Glutamate, a critical excitotoxin, has been shown to trigger a pathological rise in intracellular calcium concentrations and result in persistent contraction of vascular smooth muscle cells [16].

Intraoperative mechanical arterial manipulation causing either direct myogenic vasoconstriction or indirect stimulation of the vasa nervorum is perhaps one of the most important surgical factors. Since the 1970s animal studies have shown that direct impact or stretching of arterial vessels can cause immediate vasospasm and this was found to be a predictor for clinically significant DCI after skull base tumor surgery [4] [7] [17]. Despite compelling evidence that extent of GBM resection correlates with a stepwise improvement in overall survival, tumor encasement of the MCA limited aggressive excision in our case [18]. In retrospect, we suggest that exposed arteries be temporarily covered with cottonoids soaked with $3 \%$ papaverine solution when prolonged vessel manipulation is performed [19]. Papaverine, an effective phosphodiesterase inhibitor, has been demonstrated to relieve vasospasm and such practice is routinely conducted in our center after aneurysm clip ligation [20].

The management of post-tumor resection DCI presents unique challenges akin to trauma-related vasospasm. In SAH hypertensive and nimodipine therapy have been the mainstay of treatment after securing ruptured aneurysms [21]. In the post-tumor resection setting, as in severe traumatic brain injury, such treatment could aggravate cerebral edema or result inintracerebral hemorrhage. In the past 20 years (1994-2014), 21 cases of vasospasm following intracranial tumor resection treated by hypertensive therapy were identified. Approaching twothirds of patients (61\%) had good neurological outcomes after treatment and is evidence in support of possible clinical efficacy (Table 1) [4] [22]-[32]. From a recent review of the components of "triple-H" therapy (hyper- 
Table 1. Outcomes of brain tumor patients with postoperative DCI.

\begin{tabular}{|c|c|c|c|c|c|c|}
\hline Title & $\begin{array}{l}\text { Age/ } \\
\text { Sex }\end{array}$ & Pathology & $\begin{array}{c}\text { Postoperative Day } \\
\text { of } \\
\text { Vasospasm } \\
\text { Occurrence }\end{array}$ & Treatment & Outcome & $\begin{array}{l}\text { Time of } \\
\text { outcome } \\
\text { assessment }\end{array}$ \\
\hline Afshari 2014 & $9 / \mathrm{F}$ & $\begin{array}{l}\text { Hypoglossal nerve } \\
\text { Schwannoma }\end{array}$ & 8 & $\begin{array}{l}\text { (1) IV milrinone and noradrenaline } \\
\text { (2) Nimodipine }\end{array}$ & $\begin{array}{l}\text { Full } \\
\text { recovery }\end{array}$ & $\begin{array}{c}3 \\
\text { months }\end{array}$ \\
\hline $\begin{array}{l}\text { Rao } \\
2013\end{array}$ & $10 / \mathrm{F}$ & $\begin{array}{l}\text { Posterior fossa } \\
\text { medulloblastoma }\end{array}$ & 12 & $\begin{array}{l}\text { (1) Hypertension up to } 165 \mathrm{mmHg} \\
\text { (2) Nimodipine }\end{array}$ & $\begin{array}{l}\text { Full } \\
\text { recovery }\end{array}$ & Day 25 \\
\hline $\begin{array}{l}\text { Jacob } \\
2011\end{array}$ & $23 / \mathrm{M}$ & $\begin{array}{l}\text { Posterior fossa } \\
\text { ependymoma }\end{array}$ & 12 & $\begin{array}{l}\text { (1) HHH (NS) } \\
\text { (2) Balloon angioplasty } \\
\text { (3) IA verapamil } \\
\text { (4) Calcium-channel blocker (NS) }\end{array}$ & $\begin{array}{l}\text { Full } \\
\text { recovery }\end{array}$ & Day 24 \\
\hline $\begin{array}{l}\text { Kasliwal } \\
2008\end{array}$ & $34 / F$ & Pituitary adenoma & 13 & $\begin{array}{l}\text { (1) Hypervolemia (NS) } \\
\text { (2) IA papaverine }\end{array}$ & Mortality & Day 14 \\
\hline $\begin{array}{l}\text { Almubaslat } \\
2007\end{array}$ & $41 / \mathrm{F}$ & Esthesioneuroblastoma & 11 & $\begin{array}{l}\text { (1) HHH (NS) } \\
\text { (2) Corticosteroid } \\
\text { (3) Nimodipine }\end{array}$ & $\begin{array}{l}\text { Homonymous } \\
\text { hemianopia }\end{array}$ & Day 23 \\
\hline Ecker 2003 & $23 / \mathrm{F}$ & Sylvian dermoid cyst & 2 & $\begin{array}{l}\text { (1) HHH (NS) } \\
\text { (2) Balloon angioplasty }\end{array}$ & $\begin{array}{c}\text { Mild } \\
\text { hemiparesis }\end{array}$ & $\begin{array}{c}7 \\
\text { months }\end{array}$ \\
\hline $\begin{array}{l}\text { Nishioka } \\
2001\end{array}$ & $41 / \mathrm{M}$ & Pituitary adenoma & 12 & $\begin{array}{l}\text { (1) HHH (NS) } \\
\text { (2) IA papaverine } \\
\text { (3) Anticoagulation }\end{array}$ & Full recovery & NS \\
\hline Bejjani 1999 & $48 / \mathrm{F}$ & $\begin{array}{l}\text { Cavernous sinus } \\
\text { meningioma }\end{array}$ & 30 & $\begin{array}{l}\text { (1) HHH (NS) } \\
\text { (2) Intraaortic balloon pump } \\
\text { (3) Balloon angioplasty }\end{array}$ & $\begin{array}{l}\text { Significant } \\
\text { improvement }\end{array}$ & NS \\
\hline Bejjani 1999 & $65 / F$ & $\begin{array}{l}\text { Foramen magnum } \\
\text { meningioma }\end{array}$ & 15 & $\begin{array}{l}\text { (1) HHH (NS) } \\
\text { (2) Balloon angioplasty }\end{array}$ & Mortality & NS \\
\hline Bejjani 1999 & $50 / \mathrm{F}$ & $\begin{array}{l}\text { Cavernous sinus } \\
\text { meningioma }\end{array}$ & 4 & (1) HHH (NS) & $\begin{array}{c}\text { Significant } \\
\text { improvement }\end{array}$ & NS \\
\hline Bejjani 1999 & $57 / \mathrm{M}$ & $\begin{array}{l}\text { Petroclival } \\
\text { meningioma }\end{array}$ & 1 & $\begin{array}{l}\text { (1) HHH (NS) } \\
\text { (2) IA papaverine }\end{array}$ & $\begin{array}{c}\text { Significant } \\
\text { improvement }\end{array}$ & NS \\
\hline Bejjani 1999 & $59 / \mathrm{F}$ & $\begin{array}{l}\text { Cavernous sinus } \\
\text { meningioma }\end{array}$ & 2 & (1) HHH (NS) & $\begin{array}{l}\text { Significant } \\
\text { improvement }\end{array}$ & NS \\
\hline Bejjani 1999 & $50 / \mathrm{F}$ & $\begin{array}{l}\text { Planum sphenoidale } \\
\text { meningioma }\end{array}$ & 1 & $\begin{array}{l}\text { (1) HHH (NS) } \\
\text { (2) Balloon angioplasty }\end{array}$ & $\begin{array}{l}\text { Significant } \\
\text { improvement }\end{array}$ & NS \\
\hline Chang 1999 & $45 / M$ & $\begin{array}{l}\text { Suprasellar pilocytic } \\
\text { astrocytoma }\end{array}$ & 5 & $\begin{array}{l}\text { (1) HHH (NS) } \\
\text { (2) Nimodipine } \\
\text { (3) IA papaverine }\end{array}$ & $\begin{array}{l}\text { Aphasia, right } \\
\text { hemiparesis }\end{array}$ & NS \\
\hline $\begin{array}{c}\text { Lee } \\
1998\end{array}$ & $\begin{array}{c}15 \\
\text { months } \\
/ F\end{array}$ & $\begin{array}{l}\text { Posteriorfossa } \\
\text { primitive } \\
\text { neuroectodermal } \\
\text { tumor }\end{array}$ & 21 & $\begin{array}{l}\text { (1) IV dobutamine } \\
\text { (2) IV albumin } \\
\text { (3) Nimodipine } \\
\text { (4) Anticoagulation }\end{array}$ & Mortality & 5 weeks \\
\hline Bejjani 1997 & $6 / F$ & $\begin{array}{l}\text { Oculomotor nerve } \\
\text { Schwannoma }\end{array}$ & 7 & $\begin{array}{l}\text { (1) HHH (US) } \\
\text { (2) Balloon angioplasty }\end{array}$ & Full recovery & NS \\
\hline Cervoni 1996 & $51 / \mathrm{M}$ & Pituitary adenoma & 4 & $\begin{array}{l}\text { (1) Hypervolemia (NS) } \\
\text { (2) Nimodipine }\end{array}$ & Full recovery & 2 years \\
\hline Cervoni 1996 & $48 / \mathrm{F}$ & Pituitary adenoma & 5 & $\begin{array}{l}\text { (1) Hypervolemia (NS) } \\
\text { (2) Nimodipine }\end{array}$ & Mortality & Day 12 \\
\hline Cervoni 1996 & 38/M & Craniopharyngioma & 7 & $\begin{array}{l}\text { (1) Hypervolemia (NS) } \\
\text { (2) Nimodipine }\end{array}$ & $\begin{array}{c}\text { Significant } \\
\text { improvement }\end{array}$ & 1 year \\
\hline Cervoni 1996 & $44 / \mathrm{M}$ & $\begin{array}{l}\text { Frontal metastatic } \\
\text { adenocarcinoma }\end{array}$ & 5 & $\begin{array}{l}\text { (1) Hypervolemia (NS) } \\
\text { (2) Nimodipine }\end{array}$ & Mortality & Day 15 \\
\hline Cervoni 1996 & $51 / \mathrm{M}$ & $\begin{array}{l}\text { Petroclival } \\
\text { meningioma }\end{array}$ & 4 & $\begin{array}{l}\text { (1) Hypervolemia (NS) } \\
\text { (2) Nimodipine }\end{array}$ & Mortality & Day 10 \\
\hline
\end{tabular}

N.B. IV, intravenous; HHH = hypertension, hypervolemia, hemodilution; NS, not specified; IA, intrarterial. 
tension, hypervolemia and hemodilution) on cerebral perfusion in SAH patients, hypertension seemed to be the most effective [33]. Although there is no consensus on how hypertensive therapy should be induced, our experience indicates that elevating mean arterial pressure and systolic blood pressure to at least $20 \%$ of preoperative values can attenuate symptoms of DCI. Nimodipine has been demonstrated to improve morbidity in aneurysmal SAH by exerting neuroprotection through unspecified mechanisms and corresponding supportive evidence has also been reported from a multicenter randomized-controlled trial for traumatic brain injury [34] [35]. Although a subsequent pooled analysis of several clinical trials, conducted for patients with traumatic SAH, concluded no difference in poor outcome, we decided to give the benefit of the doubt and administered nimodipine [36].

It was apparent from our case that neuroimaging or Doppler studies are required to guide treatment duration. Our experience suggests that the partial recovery of symptoms is insufficient to presume that vasospasm has resolved and may recur should therapy be stopped prematurely. We recommend that medical management should last for more than a week and discontinued when angiographic, sonographic or perfusion studies are supportive of vasospasm resolution. More aggressive management by pharmacologic or mechanical angioplasty could be an alternative treatment optional though there exists a risk of rupture, especially during balloon dilatation, of the arterial wall potentially weakened by tumor infiltration or previous radiotherapy [1] [4].

\section{Conclusion}

Delayed cerebral ischemia due to vasospasm after GBM resection is a rare complication. When such lesions are found to encase the MCA one should balance the risks and benefits of greater extent of resection versus excessive vessel manipulation. Any new postoperative neurological deficit that cannot be explained by hemorrhage, seizures or infection should be expeditiously investigated by angiography or transcranial Doppler sonography. Prompt initiation of hypertensive (aiming at least 20\% above baseline blood pressures) and nimodipine therapy can partially reverse symptoms. Our case suggests that treatment duration should be guided by imaging studies and not by symptoms alleviation alone.

\section{Conflict of Interest}

The authors declare that they have no conflict of interest.

\section{References}

[1] Alotaibi, N.M. and Lanzino, G. (2013) Cerebral Vasospasm Following Tumor Resection. Journal of Neurointerventional Surgery, 5, 413-418. http://dx.doi.org/10.1136/neurintsurg-2012-010477

[2] Vergouwen, M.D. and Participants in the International Multi-Disciplinary Consensus Conference on the Critical Care Management of Subarachnoid H. (2011) Vasospasm versus Delayed Cerebral Ischemia as an Outcome Event in Clinical Trials and Observational Studies. Neurocritical Care, 15, 308-311. http://dx.doi.org/10.1007/s12028-011-9586-8

[3] Dorhout Mees, S.M., Kerr, R.S., Rinkel, G.J., Algra, A. and Molyneux, A.J. (2012) Occurrence and Impact of Delayed Cerebral Ischemia after Coiling and after Clipping in the International Subarachnoid Aneurysm Trial (ISAT). Journal of Neurology, 259, 679-683. http://dx.doi.org/10.1007/s00415-011-6243-2

[4] Bejjani, G.K., Sekhar, L.N., Yost, A.M., Bank, W.O. and Wright, D.C. (1999) Vasospasm after Cranial Base Tumor Resection: Pathogenesis, Diagnosis, and Therapy. Surgical Neurology, 52, 577-583. http://dx.doi.org/10.1016/S0090-3019(99)00108-1

[5] Omuro, A. and DeAngelis, L.M. (2013) Glioblastoma and Other Malignant Gliomas: A Clinical Review. Journal of the American Medical Association, 310, 1842-1850. http://dx.doi.org/10.1001/jama.2013.280319

[6] Kale, S.P., Edgell, R.C., Alshekhlee, A., BorhaniHaghighi, A., Sweeny, J., Felton, J., Kitchener, J., Vora, N., Bieneman, BK., Cruz-Flores, S. and Abdulrauf, S. (2013) Age-Associated Vasospasm in Aneurysmal Subarachnoid Hemorrhage. Journal of Stroke and Cerebrovascular Diseases, 22, 22-27. http://dx.doi.org/10.1016/j.jstrokecerebrovasdis.2011.05.024

[7] Kramer, D.R., Winer, J.L., Pease, B.A., Amar, A.P. and Mack, W.J. (2013) Cerebral Vasospasm in Traumatic Brain Injury. Neurology Research International, 2013, Article ID: 415813. http://dx.doi.org/10.1155/2013/415813

[8] Peisker, T., Bartos, A., Skoda, O., Ibrahim, I. and Kalvach, P. (2010) Impact of Aging on Cerebral Vasoregulation and Parenchymal Integrity. Journal of the Neurological Sciences, 299, 112-115. http://dx.doi.org/10.1016/j.jns.2010.08.064

[9] de Lima Oliveira, M., de Azevedo, M.K., Machado, M.F., Teixeira, M.J. and Bor-Seng-Shu, E. (2014) The Role of Metabolism in the Ischemia Associated with Vasospasm Following Brain Tumor Resection. Journal of Neurointerven- 
tional Surgery, 2014, Apr 4, Online First.

[10] Sone, M., Takahashi, K., Totsune, K., Murakami, O., Arihara, Z., Satoh, F., Mouri, T. and Shibahara, S. (2000) Expression of Endothelin-1 and Endothelin Receptors in Cultured Human Glioblastoma Cells. Journal of Cardiovascular Pharmacology, 36, S390-S392. http://dx.doi.org/10.1097/00005344-200036051-00113

[11] Ni, W., Gu, Y.X., Song, D.L., Leng, B., Li, P.L. and Mao, Y. (2011) The Relationship between IL-6 in CSF and Occurrence of Vasospasm after Subarachnoid Hemorrhage. Acta Neurochirurgica Supplements, 110/1, 203-208. http://dx.doi.org/10.1007/978-3-7091-0353-1_35

[12] Shiba, M., Suzuki, H., Fujimoto, M., Shimojo, N., Imanaka-Yoshida, K., Yoshida, T., Kanamaru, K., Matsushima, S. and Taki, W. (2013) Role of Platelet-Derived Growth Factor in Cerebral Vasospasm after Subarachnoid Hemorrhage in Rats. Acta Neurochirurgica Supplement, 115, 219-223. http://dx.doi.org/10.1007/978-3-7091-1192-5 40

[13] Nazarenko, I., Hede, S.M., He, X., Hedren, A., Thompson, J., Lindström, M.S. and Nistér, M. (2012) PDGF and PDGF Receptors in Glioma. Upsala Journal of Medical Sciences, 117, 99-112. http://dx.doi.org/10.3109/03009734.2012.665097

[14] Lafuente, J.V., Adan, B., Alkiza, K., Garibi, J.M., Rossi, M. and Cruz-Sánchez, F.F. (1999) Expression of Vascular Endothelial Growth Factor (VEGF) and Platelet-Derived Growth Factor Receptor-Beta (PDGFR-Beta) in Human Gliomas. Journal of Molecular Neuroscience, 13, 177-185. http://dx.doi.org/10.1385/JMN:13:1-2:177

[15] Roslin, M., Henriksson, R., Bergstrom, P., Ungerstedt, U. and Bergenheim, A.T. (2003) Baseline Levels of Glucose Metabolites, Glutamate and Glycerol in Malignant Glioma Assessed by Stereotactic Microdialysis. Journal of Neuro-Oncology, 61, 151-160. http://dx.doi.org/10.1023/A:1022106910017

[16] Cossu, G., Messerer, M., Oddo, M. and Daniel, R.T. (2014) To Look beyond Vasospasm in Aneurysmal Subarachnoid Haemorrhage. BioMed Research International, 2014, Article ID: 628597. http://dx.doi.org/10.1155/2014/628597

[17] Arutiunov, A.I., Baron, M.A. and Majorova, N.A. (1974) The Role of Mechanical Factors in the Pathogenesis of Short-Term and Prolonged Spasm of the Cerebral Arteries. Journal of Neurosurgery, 40, 459-472. http://dx.doi.org/10.3171/jns.1974.40.4.0459

[18] Sanai, N. and Berger, M.S. (2008) Glioma Extent of Resection and Its Impact on Patient Outcome. Neurosurgery, 62, 753-764. http://dx.doi.org/10.1227/01.neu.0000318159.21731.cf

[19] Warnick, R.E. and Petr, M.J. (2008) Complications of Surgery. In: Berstein, M. and Berger, M.S., Eds., Neuro-Oncology: The Essentials, Thieme Medical Publishers, New York, 132-140.

[20] Sabouri, M., Rahmani, P., Rezvani, M., Nikbakht, H., Rafiee, A., Torkashvand, M., Eshraghi, N., Nourian, N. and Moradi, M. (2013) The Effect of Irrigation of Intracisternal Papaverine on Cerebral Blood Flow in Subarachnoid Hemorrhage. Advanced Biomedical Research, 2, 45. http://dx.doi.org/10.4103/2277-9175.114184

[21] Bederson, J.B., Connolly Jr., E.S., Batjer, H.H., Dacey, R.G., Dion, J.E., Diringer, M.N., Duldner Jr., J.E., Harbaugh, R.E., Patel, A.B. and Rosenwasser, R.H., American Heart Association (2009) Guidelines for the Management of Aneurysmal Subarachnoid Hemorrhage: A Statement for Healthcare Professionals from a Special Writing Group of the Stroke Council, American Heart Association. Stroke, 40, 994-1025. http://dx.doi.org/10.1161/STROKEAHA.108.191395

[22] Afshari, F.T., Fitzgerald, J.J., Higgins, J.N., Garnett, M.R., Fernandes, H.M. and Santarius, T. (2014) Diffuse Cerebral Vasospasm Following Resection of a Hypoglossal Schwannoma in a Child. British Journal of Neurosurgery, 28, 541543. http://dx.doi.org/10.3109/02688697.2013.865705

[23] Rao, V.K., Haridas, A., Nguyen, T.T., Lulla, R., Wainwright, M.S. and Goldstein, J.L. (2013) Symptomatic Cerebral Vasospasm Following Resection of a Medulloblastoma in a Child. Neurocritical Care, 18, 84-88. http://dx.doi.org/10.1007/s12028-012-9769-y

[24] Jacob, J.T., Hunt, C.H., Wijdicks, E.F., Rabinstein, A.A., Cloft, H. and Link, M.J. (2011) Diffuse Cerebral Vasospasm after Resection of a Posterior Fossa Ependymoma. Neurocritical Care, 14, 86-90. http://dx.doi.org/10.1007/s12028-010-9464-9

[25] Kasliwal, M.K., Srivastava, R., Sinha, S., Kale, S.S. and Sharma, B.S. (2008) Vasospasm after Transsphenoidal Pituitary Surgery: A Case Report and Review of the Literature. Neurology India, 56, 81-83. http://dx.doi.org/10.4103/0028-3886.39322

[26] Almubaslat, M. and Africk, C. (2007) Cerebral Vasospasm after Resection of an Esthesioneuroblastoma: Case Report and Literature Review. Surgical Neurology, 68, 322-328. http://dx.doi.org/10.1016/j.surneu.2006.10.026

[27] Ecker, R.D., Atkinson, J.L. and Nichols, D.A. (2003) Delayed Ischemic Deficit after Resection of a Large Intracranial Dermoid: Case Report and Review of the Literature. Neurosurgery, 52, 706-710. http://dx.doi.org/10.1227/01.NEU.0000048482.27700.3B

[28] Nishioka, H., Ito, H. and Haraoka, J. (2001) Cerebral Vasospasm Following Transsphenoidal Removal of a Pituitary Adenoma. British Journal of Neurosurgery, 15, 44-47. http://dx.doi.org/10.1080/02688690020024391 
[29] Chang, S.D., Yap, O.W. and Adler Jr., J.R. (1999) Symptomatic Vasospasm after Resection of a Suprasellar Pilocytic Astrocytoma: Case Report and Possible Pathogenesis. Surgical Neurology, 51, 521-526. http://dx.doi.org/10.1016/S0090-3019(97)00313-3

[30] Lee, T.T., Ragheb, J., Bruce, J.C., Altman, N. and Morrison, G. (1998) Diffuse Cerebral Vasospasm with Ischemia after Resection of a Cerebellopontine Angle Primitive Neuroectodermal Tumor in a Child. Pediatric Neurosurgery, 29, 300-303. http://dx.doi.org/10.1159/000028741

[31] Bejjani, G.K., Duong, D.H., Kalamarides, M., Ziyal, I. and Sullivan, B.J. (1997) Cerebral Vasospasm after Tumor Resection. A Case Report. Neurochirurgie, 43, 164-168.

[32] Cervoni, L., Salvati, M. and Santoro, A. (1996) Vasospasm Following Tumor Removal: Report of 5 Cases. Italian Journal of Neurological Sciences, 17, 291-294. http://dx.doi.org/10.1007/BF01997789

[33] Dankbaar, J.W., Slooter, A.J., Rinkel, G.J. and Schaaf, I.C. (2010) Effect of Different Components of Triple-H Therapy on Cerebral Perfusion in Patients with Aneurysmal Subarachnoid Haemorrhage: A Systematic Review. Critical Care, 14, R23. http://dx.doi.org/10.1186/cc8886

[34] Harders, A., Kakarieka, A. and Braakman, R. (1996) Traumatic Subarachnoid Hemorrhage and Its Treatment with Nimodipine. Journal of Neurosurgery, 85, 82-89. http://dx.doi.org/10.3171/jns.1996.85.1.0082

[35] Pickard, J.D., Murray, G.D., Illingworth, R., Shaw, M.D., Teasdale, G.M., Foy, P.M., Humphrey, P.R., Lang, D.A., Nelson, R. and Richards, P. (1989) Effect of Oral Nimodipine on Cerebral Infarction and Outcome after Subarachnoid Haemorrhage: British Aneurysm Nimodipine Trial. British Medical Journal, 298, 636-642. http://dx.doi.org/10.1136/bmj.298.6674.636

[36] Vergouwen, M.D., Vermeulen, M. and Roos, Y.B. (2006) Effect of Nimodipine on Outcome in Patients with Traumatic Subarachnoid Haemorrhage: A Systematic Review. The Lancet Neurology, 5, 1029-1032. http://dx.doi.org/10.1016/S1474-4422(06)70582-8

\section{Abbreviations}

CT: computed tomography

DCI: delayed cerebral ischemia

GBM: glioblastoma multiforme

MCA: middle cerebral artery

MRA: magnetic resonance angiography

MRI: magnetic resonance imaging

PDGF: platelet-derived growth factor

SAH: subarachnoid hemorrahge

TCD: transcranial Doppler sonography 